\title{
EKSPERIMENTASI METODE CERAMAH DAN DISKUSI PADA MATA KULIAH MATEMATIKA EKONOMI DITINJAU DARI JENIS KELAMIN MAHASISWA
}

\author{
Utin Desy Susiaty ${ }^{1}$, Dwi Oktaviana ${ }^{2}$ \\ ${ }^{1,2}$ Prodi Pendidikan Matematika, Fakultas MIPATEK, IKIP PGRI Pontianak \\ d3or4f4ty4@gmail.com $^{1}$, dwi.oktaviana7@gmail.com ${ }^{2}$
}

\begin{abstract}
Abstrak
Tujuan penelitian ini untuk mengetahui: (1) manakah yang memberikan prestasi belajar yang lebih baik, metode ceramah atau metode diskusi; (2) manakah yang memiliki prestasi belajar yang lebih baik, mahasiswa laki-laki atau perempuan; (3) pada masing-masing model pembelajaran, manakah yang mempunyai prestasi belajar yang lebih baik, mahasiswa laki-laki atau perempuan; (4) pada masing-masing jenis kelamin, manakah yang memberikan prestasi yang lebih baik, metode ceramah atau metode diskusi. Penelitian ini merupakan penelitian eksperimental semu dengan populasi seluruh mahasiswa semester 5 di kelas pagi Program Studi Pendidikan Matematika IKIP-PGRI Pontianak. Pengambilan sampel dilakukan dengan teknik stratified cluster random sampling. Sampel dalam penelitian ini sebanyak 68 mahasiswa. Teknik pengumpulan data meliputi metode dokumentasi untuk mendapatkan nilai MID mata kuliah Matematika Ekonomi tahun akademik 2015/2016 sebagai data kemampuan awal dan nilai UAS mata kuliah Matematika Ekonomi untuk data prestasi belajar matematika mahasiswa. Uji hipotesis penelitian menggunakan analisis variansi dua jalan dengan sel tak sama. Berdasarkan hasil penelitian dapat disimpulkan sebagai berikut. (1) Pembelajaran matematika ekonomi menggunakan metode ceramah menghasilkan prestasi belajar matematika yang sama dengan metode diskusi. (2) Mahasiswa laki-laki maupun perempuan memiliki prestasi belajar matematika yang sama. (3) Pada masing-masing metode pembelajaran, mahasiswa laki-laki maupun perempuan memiliki prestasi belajar matematika yang sama. (4) Pada masing-masing jenis kelamin, pembelajaran matematika ekonomi menggunakan metode ceramah dan metode diskusi menghasilkan prestasi belajar matematika yang sama.
\end{abstract}

Kata kunci: metode ceramah, metode diskusi, jenis kelamin

\section{Abstract}

The aims of this study were to investigate: (1) which learning method produces student's better mathematics learning achievement, speech method or discussion method; (2) which student's have better mathematics learning achievement, male or female; (3) viewed from learning methods, which student's have better mathematics learning achievement, male or female; (4) viewed from gender, which learning method produces better mathematics learning achievement, speech method or discussion method. This research used quasi experimental method with its population included all of students of 5th semester in morning class Program Study of Mathematics Education IKIP-PGRI Pontianak. Sampling was done by stratified cluster random sampling technique. The size of the sample was 68 students. The data collection technique was include the documentation method to get the 2015/2016 MID Test of Economy Mathematics subject for initial capability data before the experiment and Final test of Economy Mathematics subject for mathematics student's achievement data. The data was analyzed using analysis of variance. Based on these results it can be concluded as follows. (1) Economy mathematics learning using speech method produced the same mathematics achievement as using discussion method. (2) For male or female students have the same mathematics achievement. (3) Viewed from learning method, male or female students have the same mathematics achievement. (4) Viewed from gender, economy mathematics learning using speech method and discussion method have the same mathematics achievement.

Keywords: speech method, discussion method, gender

\section{PENDAHULUAN}

Pendidikan seperti sifat sasarannya yaitu manusia, mengandung banyak aspek dan sifatnya sangat kompleks. Karena sifatnya yang kompleks itu, maka tidak ada sebuah batasan pun yang cukup memadai untuk menjelaskan arti pendidikan secara lengkap. Batasan tentang pendidikan yang dibuat oleh para ahli beraneka ragam, dan kandungannya berbeda yang satu dari yang lain. Perbedaan tersebut mungkin karena orientasinya, konsep dasar yang digunakan, aspek yang menjadi tekanan, atau karena falsafah yang melandasinya (Tirtarahardja dan Sulo, 2015:33). 
Sebagai suatu komponen pendidikan, tujuan pendidikan menduduki posisi penting di antara komponenkomponen pendidikan lainnya. Dapat dikatakan bahwa segenap komponen dari seluruh kegiatan pendidikan dilakukan semata-mata terarah kepada atau ditujukan untuk pencapaian tujuan tersebut. Dengan demikian, maka kegiatan-kegiatan yang tidak relevan dengan tujuan tersebut dianggap menyimpang, tidak fungsional, bahkan salah, sehingga harus dicegah terjadinya. Di sini terlihat bahwa tujuan pendidikan itu bersifat normatif, yaitu mengandung unsur norma yang bersifat memaksa, tetapi tidak bertentangan dengan hakikat perkembangan peserta didik serta dapat diterima oleh masayarakat sebagai nilai hidup yang baik. Proses pendidikan merupakan kegiatan memobilisasi segenap komponen pendidikan oleh pendidik terarah kepada pencapaian tujuan pendidikan. Bagaimana proses pendidikan itu dilaksanakan sangat menentukan kualitas hasil pencapaian tujuan pendidikan. Kualitas proses pendidikan menggejala pada dua segi, yaitu kualitas komponen dan kualitas pengelolaannya. Kedua segi tersebut satu sama lain saling bergantung. Walaupun komponen-komponennya cukup baik, seperti tersedianya prasarana dan sarana serta biaya yang cukup, jika tidak ditunjang dengan pengelolaan yang andal maka pencapaian tujuan tidak akan tercapai secara optimal. Demikian pula bila pengelolaan baik tetapi di dalam kondisi serba kekurangan, akan mengakibatkan hasil yang tidak optimal.

Yang menjadi tujuan utama pengelolaan proses pendidikan yaitu terjadinya proses belajar dan pengalaman belajar yang optimal. Sebab berkembangnya tingkah laku peserta didik sebagai tujuan belajar hanya dimungkinkan oleh adanya pengalaman belajar yang optimal itu. Di sini jelas bahwa pendayagunaan teknologi pendidikan memegang perana penting. Pengelolaan proses pendidikan harus memperhitungkan perkembangan ilmu pengetahuan dan teknologi. Karena itu setiap guru/dosen wajib mengikuti dengan saksama inovasi-inovasi pendidikan terutama yang diseminasikan secara meluas oleh pemerintah seperti PPSI, belajar tuntas (mastery learning), pendekatan CBSA dan keterampilan proses, muatan local dalam kurikulum, dan lain-lainnya agar dapat mengambil manfaatnya (Tirtarahardja dan Sulo, 2015:37-41).

Penetapan standar proses pendidikan merupakan kebijakan yang sangat penting dan strategis untuk pemerataan dan peningkatan kualitas pendidikan. Melalui standar proses pendidikan setiap guru/dosen dapat menentukan bagaimana seharusnya proses pembelajaran berlangsung. Proses pembelajaran adalah merupakan suatu sistem. Dengan demikian, pencapaian standar proses untuk meningkatkan kualitas pendidikan dapat dimulai dari menganalisis setiap komponen yang dapat membentuk dan mempengaruhi proses pembelajaran. Begitu banyak komponen yang dapat mempengaruhi kualitas pendidikan, namun demikian tidak mungkin upaya meningkatkan kualitas dilakukan dengan memperbaiki setiap komponen secara serempak. Hal ini selain komponen-komponen itu keberadaannya terpencar, juga kita sulit menentukan kadar keterpengaruhan setiap komponen.

Namun demikian, komponen yang selama ini dianggap sangat mempengaruhi proses pendidikan adalah komponen guru/dosen. Hal ini memang wajar, sebab guru/dosen merupakan ujung tombak yang berhubungan langsung dengan siswa/mahasiswa sebagai subjek dan objek belajar. Bagaimanapun bagus dan idealnya kurikulum pendidikan, bagaimanapun lengkapnya sarana dan prasarana pendidikan, tanpa diimbangi dengan kemampuan guru/dosen dalam mengimplementasikannya, maka semuanya akan kurang bermakna. Oleh sebab itu, untuk mencapai standar proses pendidikan, sebaiknya dimulai dengan menganalisis komponen guru/dosen (Sanjaya, 2013:13-14).

Sejalan dengan hal tersebut dalam pelaksanaan pembelajaran di kelas, guru/dosen dapat menggunakan berbagai metode pembelajaran yang bervariasi. Metode yang sering digunakan guru dalam mengajar yakni metode mengajar ceramah, metode ini tergolong metode konvensional karena persiapannya paling sederhana dan mudah, fleksibel tanpa memerlukan persiapan khusus (Harsono dkk, 2009:71). Menurut Sriyono (dalam Harsono dkk, 2009:71-72) metode ceramah adalah penuturan dan penjelasan guru/dosen secara lisan. Dimana dalam pelaksanannya guru/dosen dapat menggunakan alat bantu mengajar untuk memperjelas uraian yang disampaikan kepada murid-muridnya. Menurut Sanjaya (2013:147-148) metode ceramah dapat diartikan sebagai cara menyajikan pelajaran melalui penuturan secara lisan atau penjelasan langsung kepada sekelompok siswa/mahasiswa. Metode ceramah merupakan metode yang sampai saat ini sering digunakan oleh setiap guru/dosen. Hal ini selain disebabkan oleh beberapa pertimbangan tertentu, juga adanya faktor kebiasaan baik dari guru/dosen ataupun siswa/mahasiswa. Guru/dosen biasanya belum merasa puas manakala dalam proses pengelolaan pembelajaran tidak melakukan ceramah. Demikian juga dengan siswa/mahasiswa, mereka akan belajar manakala ada guru/dosen yang memberikan materi pelajaran melalui ceramah, sehingga ada guru/dosen yang berceramah berarti ada proses belajar dan tidak ada guru/dosen berarti tidak ada belajar. Metode ceramah merupakan cara yang digunakan untuk mengimplementasikan strategi pembelajaran ekspositori.

Selain metode ceramah yang sering digunakan oleh guru/dosen dalam pembelajaran di kelas salah satunya adalah metode diskusi. Strategi pembelajaran yang diduga dapat meningkatkan hasil belajar siswa/mahasiswa adalah dengan menggunakan metode diskusi. Diharapkan dengan 
penggunaan metode diskusi dapat mendorong dan memotivasi siswa/mahasiswa dalam proses belajar mengajar, sehingga dapat meningkatkan hasil belajar dan aktivitas dalam proses belajar mengajar (Anggraini, 2015:154). Metode diskusi adalah metode pembelajaran yang menghadapkan siswa/mahasiswa pada suatu permasalahan. Tujuan utama metode ini adalah untuk memecahkan suatu permasalahan, menjawab pertanyaan, menambah dan memahami pengetahuan siswa/mahasiswa, serta untuk membuat suatu keputusan (Killen dalam Sanjaya, 2013:154). Karena itu, diskusi bukanlah debat yang bersifat mengadu argumentasi. Diskusi lebih bersifat bertukar pengalaman untuk menentukan keputusan tertentu secara bersama-sama. Selama ini banyak guru/dosen yang merasa keberatan untuk menggunakan metode diskusi dalam proses pembelajaran. Keberatan itu biasanya timbul dari asumsi: pertama, diskusi merupakan metode yang sulit diprediksi hasilnya oleh karena interaksi antar siswa/mahasiswa muncul secara spontan, sehingga hasil dan arah diskusi sulit ditentukan; kedua, diskusi biasanya memerlukan waktu yang cukup panjang, padahal waktu pembelajaran di dalam kelas sangat terbatas, sehingga keterbatasan itu tidak mungkin dapat menghasilkan sesuatu secara tuntas. Sebenarnya hal ini tidak perlu dirisaukan oleh guru/dosen. Sebab dengan perencanaan dan persiapan yang matang kejadian semacam itu bisa dihindari (Sanjaya, 2013:154-155).

Matematika ekonomi adalah salah satu mata kuliah yang diajarkan di bangku perkuliahan. Deskripsi mata kuliah matematika ekonomi dapat dijabarkan sebagai berikut: 1) Aplikasi Matematika Dasar untuk Kegiatan Ekonomi, 2) Fungsi Permintaan dan Penawaran, 3) Fungsi Elastisitas dan Aproksimasi, 4) Present Value dan Future Value, 5) Aplikasi Konsep Bunga dan Diskonto, 6) Bunga Majemuk, 7) Fungsi Anuitas dan Aplikasinya, 8) Amortisasi Pinjaman. Matematika ekonomi adalah mata kuliah pilihan yang diikuti oleh semua mahasiswa program studi Pendidikan Matematika IKIP PGRI Pontianak di semester V. Banyaknya materi matematika yang diaplikasikan dalam kegiatan ekonomi pada mata kuliah matematika ekonomi ini, sehingga banyak mahasiswa yang mendapatkan nilai yang rendah. Hal ini sesuai dengan hasil ujian tengah semester (UTS) mata kuliah matematika ekonomi tahun akademik 2015/2016, rata-rata mahasiswa adalah 42,70 tergolong gagal (Tim Penyusun, 2015:37).

Dalam rangka mengoptimalkan pembelajaran matematika ekonomi, dosen juga perlu memperhatikan kemampuan siswa berdasarkan jenis kelamin (gender). Menurut Musriliani dkk (2015:52) dewasa ini guru/dosen memberikan perlakuan yang sama kepada siswa-siswanya, baik siswa laki-laki maupun siswa perempuan dengan azas kesetaraan gender. Tentu saja kesetaraan gender pada pembelajaran sangatlah penting, tetapi perlakukan yang sama mungkin adalah hal yang tidak sesuai. Umumnya kemampuan penalaran anak laki-laki dan perempuan berkembang dengan kecepatan yang berbeda atau bervariasi. Menurut American Pshychological Association (Science Daily, 6 Januari 2010) (Lestari dalam Musriliani dkk, 2015:52), berdasarkan analisis terbaru dari penelitian internasional untuk kemampuan perempuan di seluruh dunia dalam matematika tidak lebih buruk daripada kemampuan laki-laki meskipun laki-laki memiliki kepercayaan diri yang lebih dari perempuan dalam matematika. Perempuan-perempuan dari negara dimana kesamaan gender telah diakui menunjukkan kemampuan yang lebih baik dalam tes matematika.

Menurut Fazlurrachman (dalam Purwanti, 2013:112) istilah gender diketengahkan oleh para ilmuwan sosial untuk menjelaskan perbedaan perempuan dan laki-laki yang bersifat bawaan sebagai ciptaan Tuhan dan mana yang merupakan bentukan budaya yang dikonstruksikan, dipelajari dan disosialisasikan. Pembedaan ini sangat penting karena selama ini kita seringkali mencampuradukkan ciri manusia yang bersifat kodrati dan tidak berubah, dengan ciri manusia yang bersifat nonkodrati yang sebenarnya dapat berubah atau diubah. Dengan kata lain masyarakat tidak membedakan yang mana sebetulnya jenis kelamin (kodrat) dan yang mana gender.

\section{METODE}

Penelitian ini dilaksanakan di IKIP PGRI Pontianak di Kota Pontianak, Kalimantan Barat tahun akademik 2015/2016. Jenis penelitian ini adalah penelitian eksperimental semu atau quasi eksperimental dengan rancangan faktorial $2 \square 2$. Populasi dalam penelitian ini adalah seluruh mahasiswa semester 5 di kelas pagi Program Studi Pendidikan Matematika IKIP-PGRI Pontianak tahun akademik 2015/2016. Pengambilan sampel dilakukan dengan teknik stratified cluster random sampling sehingga terpilih sampel yaitu kelas A Pagi dan kelas B Pagi.

Pengumpulan data pada penelitian ini menggunakan metode tes dan dokumentasi. Sebelum eksperimen, terlebih dahulu dilakukan uji keseimbangan kemampuan awal siswa dengan uji $\mathrm{t}$ dengan terlebih dahulu dilakukan uji prasyarat untuk anava yaitu uji normalitas populasi dengan metode Lilliefors dan uji homogenitas variansi populasi dengan uji F. Pengujian hipotesis penelitian, menggunakan teknik analisis variansi dua jalan dengan banyaknya baris 2 dan banyaknya kolom 2 dengan sel tak sama dengan terlebih dahulu dilakukan uji prasyarat untuk anava yaitu uji normalitas dengan metode Lilliefors dan uji homogenitas dengan uji F (Budiyono, 2013: 163-217). 


\section{HASIL DAN PEMBAHASAN}

Hasil uji prasyarat kemampuan awal menyimpulkan bahwa semua sampel berasal dari populasi yang berdistribusi normal dan populasi yang dibandingkan mempunyai variansi yang homogen. Pada uji keseimbangan diperoleh simpulan bahwa sampel berasal dari populasi yang mempunyai kemampuan awal yang sama.

Setelah dilakukan uji keseimbangan untuk mengetahui kemampuan awal masing-masing kelompok sampel adalah sama, selanjutnya dilakukan uji hipotesis penelitian dengan hipotesisnya menyatakan bahwa H0A adalah tidak terdapat perbedaan prestasi belajar matematika antara mahasiswa yang diberikan metode ceramah dan metode diskusi, H0B adalah tidak terdapat perbedaan prestasi belajar antara mahasiswa laki-laki dan perempuan, dan H0AB adalah tidak terdapat interaksi antara metode pembelajaran dan jenis kelamin mahasiswa terhadap prestasi belajar matematika mahasiswa. Rangkuman hasil perhitungan analisis variansi dua jalan dengan sel tak sama ditunjukkan pada Tabel 1.

Tabel 1. Rangkuman Analisis Variansi Dua Jalan Sel Tak Sama.

\begin{tabular}{|c|c|c|c|c|c|c|}
\hline Sumber & JK & $\mathrm{dk}$ & RK & $\mathbf{F}_{\text {obs }}$ & $\mathbf{F}_{\alpha}$ & $\begin{array}{c}\text { Keputusan } \\
\text { Uji }\end{array}$ \\
\hline Metode (A) & 700.669 & 1 & 700.669 & 1.41 & 4.00 & $\begin{array}{r}\mathrm{H}_{0 \mathrm{~A}} \\
\text { diterima }\end{array}$ \\
\hline Jenis Kelamin (B) & 353.462 & 1 & 353.462 & 0.71 & 4.00 & $\begin{array}{c}\mathrm{H}_{0 \mathrm{~B}} \\
\text { diterima }\end{array}$ \\
\hline Interaksi (AB) & 535.277 & 1 & 535.277 & 1.08 & 4.00 & $\begin{array}{r}\mathrm{H}_{0 \mathrm{AB}} \\
\text { diterima }\end{array}$ \\
\hline Galat & 31788.821 & 64 & 496.700 & - & - & \\
\hline Total & 33378.228 & 67 & - & - & - & \\
\hline
\end{tabular}

Berdasarkan Tabel 1 dapat disimpulkan sebagai berikut. (1) Tidak terdapat perbedaan prestasi belajar matematika antara mahasiswa yang diberikan metode ceramah dan metode diskusi. (2) Tidak terdapat perbedaan prestasi belajar antara mahasiswa laki-laki dan perempuan.

(3) Tidak terdapat interaksi antara metode pembelajaran dan jenis kelamin mahasiswa terhadap prestasi belajar matematika mahasiswa.

Dari hasil perhitungan anava diperoleh bahwa H0A diterima, berarti mahasiswa yang diberikan metode ceramah dan metode diskusi memiliki prestasi belajar matematika yang tidak berbeda nyata. Hasil ini sesuai dengan hasil penelitian yang dilakukan oleh Rahmat (2010), yaitu metode diskusi dan metode ceramah dalam meningkatkan motivasi beragama sangat efektif sebagai usaha sadar dan terencana untuk mewujudkan suasana belajar dan proses pembelajaran agar peserta didik secara aktif mengembangkan potensi dirinya untuk memiliki kekuatan spiritual keagamaan, pengendalian diri, kepribadian, kecerdasan, akhlak mulia serta keterampilan yang diperlukan dirinya agar proses belajar menjadi lebuh mudah, lebih lancar, dan lebih berhasil dalam mencapai tujuan pembelajaran. Berdasarkan penelitian yang dilakukan oleh Ifadloh dkk (2012) dengan hasilnya menunjukkan bahwa ada pengaruh metode diskusi dengan pendekatan SETS dan media question card terhadap hasil belajar hidrokarbon siswa dan penelitian yang dilakukan oleh Wahida dkk (2015) yang menyatakan bahwa pembelajaran IPS dengan metode diskusi ternyata dapat meningkatkan hasil belajar siswa.

Dari hasil perhitungan anava diperoleh bahwa HOB diterima. Artinya, mahasiswa laki-laki maupun perempuan memiliki prestasi belajar matematika yang tidak berbeda nyata. Hasil ini sesuai dengan hasil penelitian yang dilakukan oleh Musriliani dkk (2015), yaitu tidak ada perbedaan kemampuan koneksi antara siswa laki-laki dengan siswa perempuan.

Dari hasil perhitungan anava diperoleh bahwa HOAB diterima. Artinya, tidak terdapat interaksi antara metode pembelajaran dan jenis kelamin mahasiswa terhadap prestasi belajar matematika mahasiswa. Hasil ini tidak sesuai dengan hasil penelitian yang dilakukan oleh Musriliani dkk (2015) dan Hasratudin (dalam Musriliani dkk, 2015) bahwa terdapat interaksi antara pembelajaran dengan gender terhadap kemampuan berpikir kritis siswa. Secara umum untuk H0AB diterima, berarti pada masingmasing metode pembelajaran, mahasiswa laki-laki maupun perempuan memiliki prestasi belajar matematika yang sama. Karena HOAB diterima, berarti pada masing-masing jenis kelamin, pembelajaran matematika ekonomi menggunakan metode ceramah dan metode diskusi menghasilkan prestasi belajar matematika yang sama. 


\section{PENUTUP}

\section{Simpulan}

Berdasarkan analisis data dari penelitian yang dilakukan serta mengacu pada perumusan masalah pada penelitian ini, dapat disimpulkan beberapa hal sebagai berikut. (1) Pembelajaran matematika ekonomi menggunakan metode ceramah menghasilkan prestasi belajar matematika yang sama dengan metode diskusi. (2) Mahasiswa laki-laki maupun perempuan memiliki prestasi belajar matematika yang sama. (3) Pada masing-masing metode pembelajaran, mahasiswa laki-laki maupun perempuan memiliki prestasi belajar matematika yang sama. (4) Pada masing-masing jenis kelamin, pembelajaran matematika ekonomi menggunakan metode ceramah dan metode diskusi menghasilkan prestasi belajar matematika yang sama.

\section{Saran}

Berikut adalah beberapa hal yang dapat disarankan. (1) Dalam proses pembelajaran di kelas, disarankan dosen dapat menerapkan metode ceramah dan diskusi karena sama-sama menghasilkan prestasi belajar matematika mahasiswa yang lebih baik. (2) Selain dari metode pembelajaran yang digunakan, guru juga dapat memperhatikan karakter masing-masing mahasiswa ditinjau dari jenis kelamin. (3) Penelitian yang dilakukan masih belum optimal, jadi sebaiknya dilakukan penelitian lanjutan sehingga mendapatkan hasil penelitian yang lebih optimal.

\section{DAFTAR PUSTAKA}

Anggraini, D. 2015. Metode Diskusi untuk Meningkatkan Hasil Belajar Siswa Kelas VB pada Mata Pelajaran IPS di SDN 002 Bagan Besar Kecamatan Bukit Kapur Kota Dumai. Jurnal Primary Program Studi Pendidikan Guru Sekolah Dasar Fakultas Keguruan dan Ilmu Pendidikan Universitas Riau. Vol. 4, no.2, hlm. 153-164.

Budiyono. 2013. Statistika Untuk Penelitian. Surakarta: UNS Press.

Harsono, B., Soesanto, \& Samsudi. 2009. Perbedaan Hasil Belajar antara Metode Ceramah Konvensional dengan Ceramah Berbantuan Media Animasi pada Pembelajaran Kompetensi Perakitan dan Pemasangan Sistem Rem. Jurnal PTM. Vol. 9, no.2, hlm. 71-79.

Musriliani, C., Marwan, \& Anshari, B.I. 2015. Pengaruh Pembelajaran Contextual Teaching Learning (CTL) terhadap Kemampuan Koneksi Matematis Siswa SMP Ditinjau dari Gender.
Jurnal Didaktik Matematika. Vol. 2, no.2, hlm. 49-58.

Purwanti, K.L. 2009. Perbedaan Gender terhadap Kemampuan Berhitung Matematika Menggunakan Otak Kanan pada Siswa Kelas I. Sawwa. Vol. 9, no.1, hlm. 108-122.

Rahmat, A. 2010. Efektifitas Metode Diskusi dan Ceramah dalam Meningkatkan Motivasi Beragama pada Mata Pelajaran PAI Siswa Kelas IX di SMP 03 dan SMP 07 Kota Gorontalo. Jurnal Dakwah. Vol. XI, no.1, hlm. 67-87.

Sanjaya, W. 2013. Strategi Pembelajaran Berorientasi Standar Proses Pendidikan. Jakarta: Kencana Prenadamedia Group.

Tim Penyusun. 2015. Pedoman Operasional Tahun Akademik 2015/2016. Pontianak: IKIP PGRI Pontianak.

Tirtarahardja, U \& Sulo, S.L.L. 2015. Pengantar Pendidikan (Edisi Revisi). Jakarta: PT Rineka Cipta.

Mathematics Education (JRAMathEdu) Vol. 1, No. 2, 9098, July 2016 